\title{
DIGITIZATION OF UKRAINIAN CULTURAL HERITAGE'S OBJECTS IN POLAND: COLLECTIONS OF ETHNOGRAPHY AND ART, PHOTO LIBRARIES, ARCHIVES
}

\author{
Olena Kozakevych \\ Ethnology Institute at the National Academy of Sciences Of Ukraine, Lviv, \\ Ukraine \\ kozakevych.olena@gmail.com
}

\begin{abstract}
The large numbers of material culture's objects that originate from Ukrainian territories of the late XIX - mid XX centuries are preserved in Polish museum and archival institutions. The main groups can be distinguished: museum collections of ethnography and art, archival documents and photo libraries (negatives and photo prints). Polish specialists, who have been digitizing such collections for long time, also deal with Ukrainian material, often involving Ukrainian scholars for attribution. A large part of the material is posted online (sometimes as separate projects), which provides an opportunity to get acquainted with Ukrainian cultural heritage of wide audience (most often associated with ethnographic Hutsul and Bojko Regions), for example, photos of Hutsuls and Hutsul life by Gonsiorovsky, Poddembsky, Dutkevych, Senkovsky. Most digitized objects are stored on institutions' servers, and scientists are given access to information during their research. Further usage of these documents by scientists is regulated by the legislation of the European Union and the relevant institution. Within the framework of Polish-Ukrainian cooperation, digital copies are transferred to Ukraine. In this way, the objects of Ukrainian cultural heritage become available for knowledge to the wide audience.
\end{abstract}

Keywords: Ukraina; Polish; Polish-Ukrainian Cooperation; Culture Heritage; Collection; Archives; Photo; Ethnography; Art.

At the beginning of the XXI century digitization of the world cultural heritage is extremely important because of some objective reasons (wars, destruction as a result of natural disasters and human participation, fragility of the materials, etc.), thousands of artefacts have been lost over the last century, particularly in Ukraine. Most of them did not have a single image or copy, which made them lost forever (Hevel, 2010), (Rybachok, 2017), (Katkova, 2007).

Ukraine and Poland, which are now independent states, have in the past joint pages of history and, consequently, cultural heritage items. Art and ethnographic works, photographs and archives are of great importance, 
which in different ways and for different reasons came from Ukraine to Poland - mainly during the late XIX - first half of the XX centuries. Items filled with Polish museum collections and archives of the period were brought by ethnographers, museum workers, private collectors, and donated; some objects got during wars, resettlement actions. The main funds were formed before World War II, within which, however, a number of exhibits (both Ukrainian and Polish) were lost or taken away.

Therefore, already having a negative experience of previous periods, in Poland the issue of preserving cultural heritage through digitization has become extremely relevant since the end of the XX century. However, the first steps in this direction were not easy, as there were several inhibitory factors. First of all, a certain isolation from the world progressive processes, when Poland was part of the countries of the socialist bloc. In particular, Poland, as a post-communist country, has long had many problems in the field of preservation of historical and cultural heritage: the absence or non-compliance with legislation, inefficient use of cultural heritage for development, unsatisfactory public funding and more. With the change of political system, a complex process of public administration reform, change of ideology, social mentality were taken place, which was manifested in the attitude to cultural heritage and preservation of the ethnos age-old traditions. The main provisions are regulated by the Constitution of Poland, for example, in Article 6 is noted: "The Republic of Poland shall provide conditions for the people's equal access to the products of culture which are the source of the Nation's identity, continuity and development» (Hevel, 2010).

Since the Republic of Poland became a full member of the European Union on May 1, 2004, the country has been active in preserving cultural heritage, in particular through digitization. With strong financial support from the EU and attracting state and, in particular, philanthropic funds, a number of projects have been launched in this direction. For 15 years, Poland has initiated models for the implementation of cultural policy, which regulates the formation and implementation of state administration for historical and cultural heritage; an appropriate strategy has been developed, a number of laws regulating these processes have been 
adopted, and the experience of other states has been borrowed (Sych, 2014).

Digitization priorities are given Polish heritage items of world importance. However, some projects involve recording works of art or archival documents from the so-called «Eastern Kresy» (Kresy Wschodnie) territories that at one time were part of the Polish-Lithuanian Commonwealth. These included part of the territory of Ukraine.

The author had the opportunity to get acquainted with the practical experience of Polish colleagues, to study a number of digitized collections and originals as a result of Polish-Ukrainian cooperation and during the XX edition «Thesaurus Poloniae» - Fellowship of the Minister of Culture and National Heritage of the Republic of Poland implemented by the International Cultural Centre in Krakow in 2019.

Given the large amount of material, I will focus only on some examples of digitization of Ukrainian cultural heritage in Poland, which are of great importance for Ukraine and make new relevant vectors of cooperation.

Thus, the possibility of using modern digital equipment and active Ukrainian-Polish cooperation in the direction of preserving the cultural heritage of both countries gives positive results. For example, in 2019 to Ukraine in the funds of Vasyl Stefanyk National Scientific Library of Ukraine (Lviv) digitized copies of documents, archival and manuscript collections of the Taras Shevchenko Scientific Society were transferred from Poland, the originals of which are kept in the National Library of Poland in Warsaw and the Ossolinski National Institute in Wroclaw. These archives in 14 boxes were moved from Lviv to Poland in 1944.

However, it is necessary writing a little more about the Taras Shevchenko Scientific Society (NTSh) to understand its significance in Ukrainian history and culture and the importance of transmitting these documents to Ukraine. The society was established December 23, 1973 in Lviv as Taras Shevchenko Literary Society; in 1892 the name was changed to the Taras Shevchenko Scientific Society and was some kind of first Ukrainian Academy of Sciences. Special scientific and organizational progress was made under the chairmanship of Mykhailo Hrushevsky (1897-1913). It was liquidated by the Soviet authorities in 1939; activities resumed in 1947 in 
Western Europe and the United States, where it became known as Shevchenko Scientific Society. Its branches continued to work in the USA, Canada, Australia, and France. Since 1989, the organization starts to function in Ukraine again. The most well-known personalities, whose scientific achievements became the basis for scientists of the XX - early XXI centuries were: Ivan Franko, Volodymyr Hnatiuk, Mykhailo Hrushevskyi, Volodymyr Shukhevych, Volodymyr Kubiiovych, Vasyl Shchurat and others. The main serial edition of NTSh during all periods of its existence became «Notes of NTSh» (ZNTSh) founded in 1892 and which is published to this day. The funds of antiquities, manuscripts, magazines, books, collections of Ukrainian antiquities and folklore collected under the auspices of the NTSh are the golden fund of Ukrainians, have a special priority character, as they are in the vast majority chronologically the first national collections'.

Thus, the total number of scanned images of NTSh documents which were passed to Ukraine, exceeds 240,000 digital copies (pages of documents, photo etc.; total volume over 5 terabytes). Among the digitized documents from the National Library in Warsaw are copies of the archives of the Legion of Ukrainian Sich Riflemen (1914-1918), the Ukrainian National Democratic Union (1922-1938), the Prosvita Society in Lviv (1892-1939), editors of the magazine "Life and Knowledge» in Lviv (1923-1939), the Ukrainian Public Committee for the Salvation Ukraine (1933-1934), Ukrainian education and schooling in the Second Polish-Lithuanian Commonwealth (1922-1938), the government of the Ukrainian National Republic (19181919), Ukrainian Galician Army (1918-1920), the government of the Western Ukrainian National Republic (1918-1919) and others. In addition to diaries and memoirs (1914-1922), copies of personal archives of Ivan and Jurii Lupa, Dmytro Dontsov, Olena Kysilevska, Volodymyr Kysilevskyi, Andrii Zhuk, Jevhen Arkhypenko were obtained, as well as memoirs of General Myron Tarnavsky (Kupchynskyj, 2010). The idea of organizing, studying and processing Ukrainian archives in Poland arose in 1988. During this period, more than 5 million digitals copies were made. These materials were

\footnotetext{
${ }^{1}$ Solemn transfer of digitized copies of documents of archival and manuscript collections of the Shevchenko Scientific Society. [Урочиста передача оцифрованих копій Аокументів архівних та рукописних збірок Наукового товариства імені Шевченка -

http://www.Isl.Iviv.ua/index.php/uk/2019/10/08/urochysta-peredacha-otsyfrovanyh-kopijdokumentiv-arhivnyh-ta-rukopysnyh-zbirok-naukovogo-tovarystva-imeni-shevchenka-2 (Last visited:5-01-2021)]
} 
sponsored by these Polish institutions and, in fact, are the result of long-term (over 16 years) cultural and scientific Ukrainian-Polish cooperation, in this case - between these three libraries.

The Polish digital archives contain large numbers of photographs depicting folk characters in traditional dress, architecture (secular and sacral), landscapes, art works fixed in Ukraine in the late XIX - first third of the $\mathrm{XX}$ centuries. The most famous photographers of the time were Julian Dutkevych (Juliusz Dutkiewicz), Alfred Silkevych (Alfred Silkiewicz), Henrikh Honsiorovskyi (Henryk Gasiorowski), Henrikh Poddembinskyi (Henryk Poddębski), Jurii Senkovskyi (Jurij Seńkowskyj). Their photographs transferred the folk atmosphere of the Ukrainian ethnographic territories, thus attracting the attention and interest of foreign researchers. The photographic heritage of each of these photographers deserves a separate study, which is what Polish scientists are working on now (Plazhevsky, 2003).

Most often there are materials that represent the material culture of the Hutsul Region (mostly before World War II), much less often - Boiko and Lemko Regions. The photos often were reproduced. As a result, the same images can often be seen on the websites of various institutions (the National Digital Archive, the Polish Academy of Sciences, the National Museum in Warsaw, etc.). Old photonegatives (photoplates, negatives on glass plates), which are digitized and posted on websites, have a higher cost. [Fig. 1]

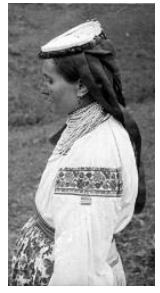

Fig.1. Woman, folk type, 1930, Bojko region,

Volosyanka, Skoliv district, Lviv region. Photo by R. Raifus. Archive of the Museum of Folk Construction in Sanok

A major Polish project for the preservation of cultural heritage through digitization is the National Digital Archive (Narodowe Archiwum Cyfrowe, NAC), are one of three central archives in Poland. 
The institution aim is the formation of a modern society that is aware of its past. NAC encourages the discovery and revitalization of heritage, teaches how to use a rich history. An important role is attached to the archival materials' digitization, in particular, the creation of effective access through appropriate systems. The archive of the NCA today has 16 million photographs, 40 thousand records and about 2.4 thousand films. Szukajwarchiwach.gov.pl - it is an online service that actually contains copies from Polish archives.

Among the numerous collections of the National Digital Archive that are relevant to the publication issue is the Fond of Henryk Poddembskyi (1870 - 1945) (Archiwum fotograficzne Henryka Poddębskiego) which contains 22798 digital photos. His heritage is characterized by a high artistic and technical level. Photographs from Ukrainian lands were taken during the 1920s and 1930s, when Poddembskyi traveled with the geographer and local historian Mechyslaw Orlovych (Mieczysław Orłowicz) through the territory of the Second Polish-Lithuanian Commonwealth. The Hutsul Region has a separate block containing 167 objects. These are mostly Hutsul types.

[Fig. 2; Fig. 3]

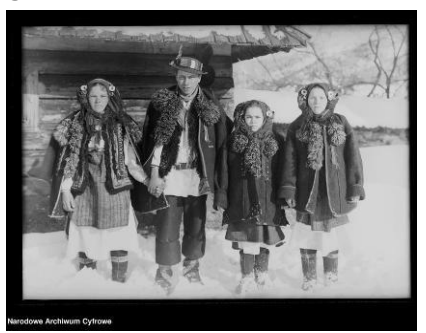

Fig.2. Photographer - Henryk

Poddebski. On the left - brides, on the right - bridesmaids. Wedding photo, Hucul region, Zhabje (Verchovyna), 1935. NAC, Archiwum fotograficzne Henryka Poddębskiego. 3/131/0/-/455/20

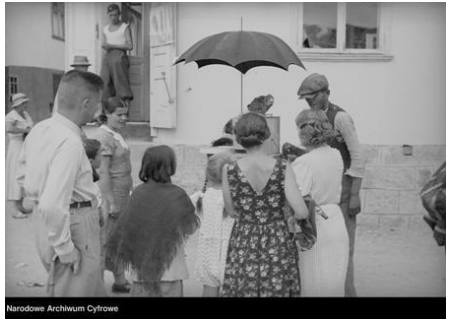

Fig.3. Photographer Henryk Poddebski. On the market in Kosiv. Hucul region, 1936. NAC, Archiwum fotograficzne Henryka Poddębskiego. 3/131/0/-/455/58

The Hutsul Region is also represented on the NCA website by several photos in the album «National Minorities» (Mniejszości narodowe). 
Photographs by Julian Dutkevych, who has his own photo studio in Kolomyia (Ivano-Frankivsk Region) and Lviv are also uploaded in some Polish sites. He became well-known due to a series of photographs of folk types and landscapes taken during the Ethnographic Exhibition in Kolomyia in 1880 (modern Ukraine, Ivano-Frankivsk Region). These photos are also stored in Ukraine, but they are not digitized. This makes it difficult for scientists to study them. However, it is possible to find them on the websites of Polish digital libraries, where photos are freely available. [Fig. 4]

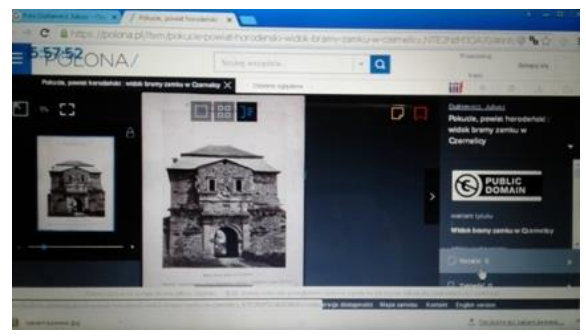

Fig.4. Site interface POLONA with the image of Chernelytsky castle and collecting the best items from museum institutions throughout Poland.

Pokuttia, about 1880. Photographer Juliush Dutkevich (Juliusz Dutkiewicz)

The next Polish big digital project is "POLONA": online library, where collections of materials of the National Library and some other cultural institutions in Poland are presented. There were many publications (exhibitions ' catalogs, art and ethnographic works, magazines, maps, music, etc.), which were published on the Ukrainian territories that were part of the Polish-Lithuanian Commonwealth. Since January 2017, Polony's collections have been replenished thanks to the Patrimonium project - the digitization and access to the Polish national heritage from the funds of the National Library and the Jagiellonian Library. ("Patrimonium - digitalizacja i udostkpnienie polskiego dziedzictwa narodowego ze zbiorów Biblioteki Narodowej oraz Biblioteki Jagiellońskiej").

Works of art and ethnography are also freely available on museum websites. Of course, preference is given to national collections. However, considering the interest of researchers in certain topics (in particular, the Hutsul Region or Kresy Wschodnie), other collections are digitized. The website of the National Museum in Krakiw has a separate section «Digital 
Collections» (Zbiory cyfrowe). The required items can be found in the «Theme Gallery», "Catalog» or by searching. For example, by writing the word «Hutsul» you will get access to 104 objects. Mostly these are folk art's items: metal adornments (crosses, necklaces («zgarda»), rings), «pysanka`s» (or Easter eggs) - ceremonial painted eggs, horn additions, as well as sacral objects (53), including icon painting. In addition, the National Museum in Krakiw in 2008 organized a grand exhibition dedicated to the art of the Hutsul Region, collecting the best items from museum institutions throughout Poland. [Fig. 5]

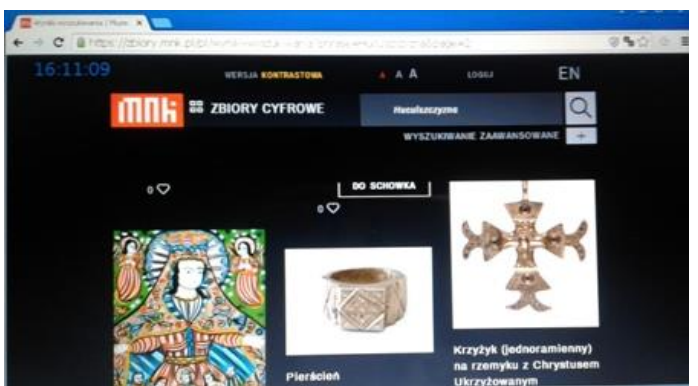

Fig.5. Site interface with the image of Hutsul art and collecting the best items from museum institutions throughout Poland.

\section{National Museum in Krakow}

The issue about digitization of Ukrainian cultural heritage in Poland is much broader. After all, much more can be written about each institution, each resource, collection or collaboration. The current pace of digitization in Poland is a positive experience for Ukraine. First it should encourage Ukrainian governing structure to introduce similar practices in Ukraine. After all, historically important documents stored in Ukrainian archives, libraries and museums due to the lack of digitization are not very accessible to researchers. Polish practice has demonstrated the relevance of digitization in the context of the COVID-19 pandemic in 2020, when the ability to use funds directly in institutions is limited as much as possible or completely. Access to digitized materials is extremely importance for Ukrainian scientists, because, first it is free (after all, like most these services in Polish institutions). In Ukraine, ordering a copy or the right to take a photo yourself is mostly on a 
paid basis. During researching in Poland, the author has opportunity to work and to obtain digital copies of numerous of ethnographic materials. For example, due to the unsatisfactory condition of the periodical "Kłosy" (Warsaw, 1865-1890) its copies in the Jagiellonian Library do not give out, but they in digital form for free access are presented. However, if the reader needs a high-quality scan of the image, it can be ordered from the library. The situation is the same in the archives: the author was provided with digital copies of cases, which protects the documents from unnecessary damages. But if the researcher needs to get acquainted with the original - it is given out in most cases.

The priority of the multi-year program «CULTURE+» (Poland) is to promote the development of mass digitization of cultural heritage. For this purpose, networks of digitization laboratories have been established, in particular in libraries, museums and state archives throughout Poland. The program also includes support for the digitization and sharing of cultural resources owned by non-governmental organizations, churches and universities. The Digital Poland program, which aims to create a digital resource of documents of government agencies, funded by the EU (Robinson, 2012).

In Ukraine, digitization processes are continuing, but much slower. In 2013, the Cabinet of Ministers of Ukraine approved the «Strategy for the Development of the Information Society in Ukraine/ until 2020. One of the priority areas of the "Strategy» is the development of electronic culture (eculture). Its main task is to create electronic versions of cultural heritage stored in libraries, museums, archives, fine arts (painting, graphics, sculpture), as well as immobile cultural heritage (architecture, landscape), cinema, television and more. The «Strategy» provides the digitization archival, library, museum funds' documents, other collections of cultural institutions and the creation of electronic information retrieval systems for history, culture, folk art, contemporary art of Ukraine, including increasing the level of preservation of documents from National Archival Fund. It also provides the implementation of the pilot project «Unified Information System of Documentary Heritage Property). The results and positive progress of the enact "Strategy» will depend on public policy and awareness of the importance of preserving cultural heritage for future generations. 


\section{LITERATURE ( $А$ LEPATYPA)}

Hevel, K. (2010). Preservation of cultural heritage in the post-communist countries of the European Union. Актуальні проблеми Аержавного управління 2010, ISSN 1684-8489, 74-77. // [(Гевель 2010) Гевель К. Збереження культурної спалщини у посткомуністичних країнах Євросоюзу. - Актуальні проблеми Аержавного управління 2010, ISSN 1684-8489, с.74-77].

Katkova, T. (2007). UNESCO's work in the field of cultural heritage preservation: legal aspects. Kharkiv: Tytul 2007, 180 s. // [(Каткова 2007) Каткова Т. Аіяльність ЮНЕСКО у сорері збереження культурної спалщини: правові аспекти. Харків : Титул 2007, ISBN 978-966-2982-19-0, 180 с.]

Kupchynskyj, O. (2010). Scientific Society Shevchenko in Lviv. Encyclopedia of the History of Ukraine. - Institute of History of Ukraine, National Academy of Sciences of Ukraine 2010, Т. 7, s. 203-728 // [(Купчинський 2010) Купчинський, О. Наукове товариство ім. Шевченка у Аьвові. Енциклопедія історії України : у 10 т. (редкол.:В. А. Смолій (голова) та ін.) ; Інститут історії України НАН України. - К. : Наук. Аумка 2010 T. 7, с. 203-728 с. : і^. — ISBN 978-966-00-1061-1.]

Plazhevsky, I. (2003). The history of Polish photography 1839-1939, Sunderland, Warszawa: Książka i Wiedza 2003, 447 p. ISBN 83-05-13316-8. // [(Płażewski 2003) Płażewski I. Dzieje polskiej fotografii 1839-1939, Sunderland, Warszawa: Książka i Wiedza 2003, 447 s.]

Robinson, H. (2012). Remembering things differently: museums, libraries and archives as memory institutions and the implications for convergence. Museum Management and Curatorship 2012, ISSN 0964-7775, Vol. 27, Issue 4. [http://www.tandfonline.com/doi/full/10.1080/09647775.2012.720188? src=recsys] Last visited: 12-04-2020

Rybachok, O. (2017). UNESCO activities in the field of development of international projects of digital documentary heritage. - Gilea 2017, SSN 2076-1554, (126), 136141. // [(Рибачок 2017) Рибачок О. Аіяльність ЮНЕСКО в галузі розвитку міжнародних проектів цифрової Аокументальної спалщини. - Гілея: науковий вісник, ISSN 2076-1554, Київ 2017, (126), с.136-141.]

Sych, O. (2014). Use of EU funds to finance urban revitalization (Polish experience). Socio-economic problems of modern Ukraine 2014, 4 (108), 208-214. // [(Си4 2014) Сич О. Використання коштів ЄС Аля фрінансування ревіталізації міст (АосвіА Польщі). Соціально-економічні проблеми сучасної України 2014, 4 (108), c.208-214. ISSN 2071-4653.] 


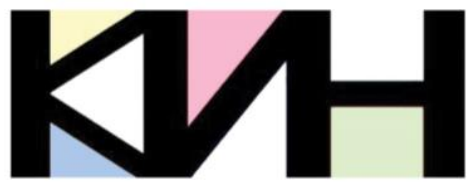

КУАТУРНО-ИСТОРИЧЕСКО НАСАЕАСТВО:

ОПАЗВАНЕ, ПРЕАСТАВЯНЕ, АИГИТААИЗАЦИЯ

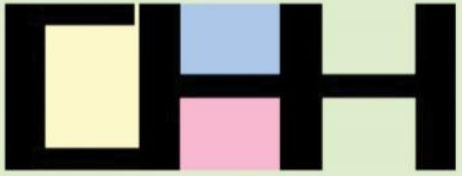

CULTURAL AND HISTORICAL HERITAGE: PRESERVATION, PRESENTATION, DIGITIZATION
Материалите в сборника са обект на авторско право. Разрешава се безвъзмезАното ползване на техни електронни/ хартиени копия само за лична употреба или обучение, при пь^но цитиране на текущата страница и слеА писмена декларация от цитиращия за мипса на търговски намерения.

(с) Авторски колектив, 2020

Техническо реАактори: Калина Сотирова-Вълкова Николай Ноев Паска^ Пиперков

\section{Editors}

Petko St. Petkov

Galina Bogdanova

This work is subject to copyright. Open and free of charge use of digital/hard copies of publications is granted only for personal or educational use, with full citation of the current page, and after written declaration of the quoting side for notcommercial Intention.

(C) Authors` Group, 2020

Technical editors:

Kalina Sotirova-Valkova

Nikolay Noev

Paskal Piperkov

НАЦИА регистрационен № 1209

Научна пореАица: том 6, брой 2 (9)/2020

Science series: vol. 6 , issue $2(9) / 2020$

NCID Registry No. 1209

www.math.bas.bg/vt/kin

ISSN: 2367-8038 